Article

\title{
Dimensions of Football Stadium and Museum Tour Experiences: The Case of Europe's Most Valuable Brands
}

\author{
Ana Brochado ${ }^{1, *}$, Carlos Brito ${ }^{2}$, Adrien Bouchet ${ }^{3}$ and Fernando Oliveira ${ }^{4}$ \\ 1 Centre for Socioeconomic and Territorial Studies (DINÂMIA'CET), ISCTE—Instituto Universitário de Lisboa, \\ 1649-026 Lisbon, Portugal \\ 2 Faculty of Economics, University of Porto, 4200-464 Porto, Portugal; cbrito@fep.up.pt \\ 3 Collins College of Business, The University of Tulsa, Tulsa, OK 74104, USA; adrien-bouchet@utulsa.edu \\ 4 ISCTE-Instituto Universitário de Lisboa, 1649-026 Lisbon, Portugal; fernando.oliveira@iscte-iul.pt \\ * Correspondence: ana.brochado@iscte-iul.pt
}

check for

updates

Citation: Brochado, A.; Brito, C.; Bouchet, A.; Oliveira, F. Dimensions of Football Stadium and Museum Tour Experiences: The Case of Europe's Most Valuable Brands. Sustainability 2021, 13, 6602. https://doi.org/10.3390/ su13126602

Academic Editor: Tomás

F. Espino-Rodríguez

Received: 19 May 2021

Accepted: 6 June 2021

Published: 9 June 2021

Publisher's Note: MDPI stays neutral with regard to jurisdictional claims in published maps and institutional affiliations.

Copyright: (c) 2021 by the authors. Licensee MDPI, Basel, Switzerland. This article is an open access article distributed under the terms and conditions of the Creative Commons Attribution (CC BY) license (https:/ / creativecommons.org/licenses/by/ $4.0 /)$.

\begin{abstract}
In the context of football's globalisation, some of the most important football clubs (FCs) can currently be classified as 'entertainment multinationals'. Sport hospitality provides opportunities to maximise club stadiums' use so that they can increase clubs' annual turnover and function as branding platforms. This study sought to identify the main narratives shared online about-and the dimensions of-visitors' experiences with top football brands in stadium tours. The data collected for this research comprised 400 text reviews for 10 European FCs' stadiums (i.e., 4000 reviews) written by visitors in the post-experience phase. Content analysis of these Web reviews was conducted using Leximancer software. The results confirm the existence of 15 themes: fan, tour, stadium, team, museum, room, staff, game, (best) place, ticket, seating, recommend(ation), food, shop and attraction. Most researchers have examined stadium tours from a supply-side perspective. The present study's aim was, therefore, to contribute to the existing literature by analysing stadium tours' dimensions from the visitors' point of view. Stadium tours and museum visits are important sources of revenue that contribute to FCs' economic sustainability. Offering outstanding customer experiences is thus of utmost importance to maximise club stadiums' usage and strengthen fans' engagement.
\end{abstract}

Keywords: stadium tour; football museum; visitor experience; web review

\section{Introduction}

Football-also known as soccer-is one of the world's most popular and engaging sports $[1,2]$. The football team core product has been defined as a 'series of league games with an uncertain outcome' [3] (p. 404), but, according to Pritchard et al. [4], the cited definition does not cover all of football stadiums' current uses. These facilities offer more products and services than just sport [5]. Football fans and tourists can visit stadiums not only to attend live sport events but also to consume football brands on non-match days [5].

The sport hospitality business has become an opportunity to maximise club stadiums' usage [5] so that they increase yearly turnovers [6] and function as branding platforms [1]. Stadiums offer diverse complementary services, such as stadium tours [5] combined with other facilities including club museums, merchandising shops and restaurants and/or cafés that create retail experiences [7]. These tours are an important component of stadiums business [8].

Stadiums have gained social significance, which fosters a 'topophilic relationship' between football fans and their teams [9]. Stadiums can be viewed as beloved places as they represent the teams' home and possess sentimental and historical significance [9]. Because these facilities are recognised as football teams' abode, they become part of heritage and tourism landscapes that offer powerful tourism experiences [7]. Club stadiums are also seen as important city tourism attractions that provide visitors with novel, memorable experiences [5]. Football clubs (FCs) have consolidated these venues so that they can 
contribute to these clubs' economic sustainability by offering fresh experiences that increase fans' engagement, consumption and co-creation [10]. Stadium tours, in particular, can generate a greater familiarity with stadiums than match days do as visitors are able to visit both frontstage and backstage areas.

In the context of football's globalisation [2], some of the most important FCs can currently be classified as 'entertainment multinationals' [5]. Club stadiums and museums have international appeal [2]. Despite these facilities' importance as heritage and tourism attractions [7], only a few studies have analysed stadium experiences on non-match days. Most researchers have examined stadium tours from a supply-side perspective (e.g., [5,7,8]). The present study's aim was, therefore, to contribute to the existing literature by analysing stadium tours' dimensions from visitors' point of view.

Visitors evaluate their experiences online for everyone to see [11]. Peer-to-peer content posted on Web-based platforms has various merits, such as spontaneity, trustworthiness and ready availability, making Web reviews a rich vein of data in terms of examining sport tourists' experiences [12]. The current research thus analysed narratives shared online by stadium tour consumers. The central question addressed was as follows: What are the main narratives shared online about-and the dimensions of — visitors' experiences with top football brands in stadium tours?

This paper is divided into five sections. After the introduction, the literature review discusses the main papers published dealing with football stadium tours and FC museums. In addition, section two provides an analysis of previous research seeking to identify the main service quality dimensions regarding daily tours and museum visits. The methodology section identifies this study's research context, namely, 10 European football brands with high value listed in Brand Finance's [13] report, as well as the methods applied. The fourth section presents the results, and the final section comprises the discussion, implications and limitations.

\section{Literature Review}

\subsection{Football Stadium Tours}

Football stadiums are not only functional utilitarian buildings for practicing sport but also iconic symbols of local and international heritage [8]. Contemporary stadiums are used for more than sport events, often serving as entertainment venues [14]. Tours are also an important component of stadiums' business. Guided visits 'have become the central way in which the stadium has become a commodity' [15] (p. 18), and tours reinforce these venues' authenticity by offering visitors access to different areas of stadiums.

Previous studies have analysed stadium tours mainly from a supply-side perspective $[5,7,8,15]$. For example, Ginesta [5] examined the business models of seven Spanish football venues classified as Category 4 Union of European Football Associations stadiums. The cited author analysed the content of corporate websites and corporate catalogues and conducted semi-structured interviews with each club's marketing managers. Ginesta [5] concluded that these clubs maximise their stadium's use by developing hospitality and event packages to increase revenues.

The football hospitality business was defined by the above author based on three parameters. First, on match days, stadiums attempt to maximise revenues by enhancing different stakeholders' experiences. Second, these facilities are viewed as symbolic places because of not only football brands but also sponsor brands. Last, stadiums have two dimensions, that is, their architecture and their symbolic representation of the teams' home to fans, and thus stadiums are city branding assets. The third dimension is developed through hospitality packages targeting visitors.

Gammon and Fear [8] studied the case of Millennium Stadium tours in Cardiff in the United Kingdom (UK) and concluded that stadium tours' success relies on the opportunity given to visitors to experience the authentic backstage area. The cited researchers stated, 'stadium tours offer visitors the opportunity to enter and/or view areas otherwise reserved for the very few' [8] (p. 244). Tour settings include frontstage and backstage areas, giv- 
ing visitors insights into not only the stadiums' public sections but also hidden and/or restricted areas. According to Gammon and Fear [8], tours include opportunities to see what the stadium looks like on non-match days and to gain access to areas occupied by 'very important people' (VIPs) on match days (e.g., executive boxes). Other components are restricted zones often shown in media coverage (e.g., press rooms) and areas used by team players (e.g., changing rooms).

Stadium tours in sports other than football have also been analysed. Ramshaw and Gammon [7], concentrated on Twickenham Stadium tours of rugby facilities, using a combination of document analysis, interviews with tour guides and observations of tour guides' narratives. These guides shared both historical and technical (e.g., pitch maintenance) details about the stadium with visitors. Ramshaw and Gammon [7] concluded that this stadium is linked with the concept of home from both a heritage and tourism perspective. The above study revealed that the stadium was represented during tours in three different ways: the England national rugby team's home, rugby's spiritual home and London as a home base.

Ramshaw et al.'s [15] study analysed the heritage construction achieved through tours of the Bank of America Stadium, which is the home of the Carolina Panthers of the United States (US) National Football League. The cited authors applied three types of methods: analysis of tours' promotional documents, examination of the virtual tour on the stadium's website and observations of tour guides during tours. Ramshaw et al. [15] identified three different types of heritage construction: the stadium and/or team owner's identity, the stadium experience (i.e., what attending a live game feels like) and imagined and future performances.

\subsection{Football Museums}

Museums are generally identified as facilities housing collections or exhibitions of heritage items, with the intent to contribute to education, research and enjoyment [1]. The number of football museums has increased [2], and they can be visited as part of guided tours [1]. These museums have distinctive characteristics compared with other museums as football exhibitions combine rational, intellectual and physical material associated with football that is connected with emotions, the body and performances [2]. These museums are located in or near football stadiums, thereby creating a 'being here' feeling. Football museums offer unique presentations of the game's public history (i.e., instead of a purely historical angle). In addition, 'historically significant' objects such as trophies become exhibits. Overall, museums seek to re-create a stadium-like atmosphere.

Contemporary club museums present 11 types of stories: creation myth, founding fathers, the stadium, the shirt, the fans, overseas connections, international players, the finest hour, the academy, legends and/or heroes and trophies [1]. As tourists can visit museums or halls of fame at all times, football museums are considered sport heritage-based tourism attractions [16]. According to Ramshaw, Gammon and Tobar [17], sport museums face challenges due to the need to address cultural and economic aims simultaneously.

Previous studies of football museums have covered different geographical areas such as Australia [16], South Africa [18], the UK [1], both the UK and China [2] and Portugal [19]. For instance, Frost [16] studied the Australian Football League Hall of Fame's financial sustainability using secondary data. The study concluded that this museum's failure was the result of simultaneous difficulties generated by high prices, overconfidence in the core concept and a location in a new shopping centre in the central business district instead of being close to FC sport facilities.

In Cape Town, Rassool and Slade [18] examined the District Six Museum and the ways that the methods used to present new exhibitions help visitors understand how football ties into South Africa's society, including issues such as race and identity formation, politics and resistance to apartheid. Appel's [1] research further focused on FC museums in the UK and investigated whether football museums match the International Council of Museums definition of museums as non-profit, permanent and open. The above author collected 
data on the Arsenal, Chelsea, Manchester United and Wolverhampton Wanders museums. Appel's [1] analysis revealed that the role football museums currently play differs from sport museums in general as FC museums act as branding platforms and seek to make a profit.

Magalhães et al. [19] examined the case of the FC Porto museum, which is located inside the Dragão Stadium, using secondary data sources. The cited study concluded that the museum is part of tourism and cultural itineraries within the city of Oporto, Portugal. Magalhães et al.'s [19] study highlighted a wide range of events and activities throughout the year that target different audiences, such as workshops, summer camps and corporate events. Yang [2] investigated the UK's National Football Museum in Manchester and China's Linzi Football Museum in Zibo based on exhibition approaches, activity programmes and cultural settings. According to the above author, football museums not only represent the sport's history but also strengthen collective identities for football enthusiasts.

\subsection{Tours and Museums' Service Quality and Overall Experience}

Although previous studies of football stadium tours have mainly taken a supply-side approach, the literature includes measurement instruments for daily tours [20] and art and specialist museums (e.g., $[11,21,22])$ that may be relevant to the present research. Most prior studies have adopted a quantitative approach using surveys and scale development techniques. One exception is Su and Teng's [11] work on identifying the main service quality dimensions based on negative reviews of museums shared online on Tripadvisor. The above researchers' content analysis of unfavourable Web reviews of art and specialty museums found 12 dimensions: convenience, contemplation, assurance, responsiveness, reliability, tangibles, empathy, communication, servicescape, consumables, purposiveness and first-hand experience.

Measuring service quality in services is a complex task as service processes include four primary characteristics: heterogeneity, intangibility, simultaneous production and consumption and perishability [23]. Caber and Albayrak [20] developed a specific scale to measure service quality in daily tours-DAILYSERV. This instrument includes the following dimensions: transportation, tour guide, food and beverage facility, shopping facility, stopover facility and museums and sites. Cheng and Wan [21], in turn, used the HISTOQUAL scale to assess service quality in museums in Macau. This scale is a modified version of the SERVQUAL scale developed by Frochot and Hughes [24] for heritage contexts such as museums, which encompasses the dimensions of responsiveness, tangibles, communication, consumables and empathy.

In addition, Cheng et al. [22] adapted the SERVQUAL model to measure service quality in museums, as well as developing the Museum Interpretation Quality Questionnaire. The latter includes the dimensions of tangibles, reliability, empathy, assurance and communication. Cheng et al.'s [22] study was conducted in museums in China and Taiwan. Conti, Vesci, Castellani and Rossato [25] identified six dimensions of museumscapes in Italy that have a positive impact on visitors' word of mouth, namely, ambient conditions, facilities and convenience, signs and signage, staff behaviour, art gallery quality and exhibition space aesthetics.

The literature on museums includes discussions of a shift from a focus on collections to audiences and from product-oriented to service-oriented processes, as these institutions have identified visitors' experience as museums' core offer [26]. Visitors' service encounters in museums are diverse and encompass subjective mental states felt by guests [27] such as escaping from everyday life, joining learning activities, sharing valued time with peers and experiencing emotional states of fun and enjoyment [28]. Museum experiences can further be classified into four categories: objective, cognitive, introspective and social [29]. 


\section{Methodology}

\subsection{Research Context}

The present study focused on 10 of the strongest and most valued football brands according to Brand Finance [13] (Table 1). These FCs belong to the top 5 European Leagues: Premier League (UK), La Liga (Spain), Bundesliga (Germany), Serie A (Italy) and Ligue 1 (France).

Table 1. Top European football brands selected.

\begin{tabular}{ccccc}
\hline Football Brand & League & Country & Stadium & $\begin{array}{c}\text { Brand Finance } \\
\text { 2019 Rank }\end{array}$ \\
\hline Arsenal FC & Premier League & UK & Emirates Stadium & 9 \\
Chelsea FC & Premier League & UK & Stamford Bridge & 7 \\
FC Barcelona & La Liga & Spain & Camp Nou & 3 \\
FC Bayern Munich & Bundesliga & Germany & Allianz Arena & 4 \\
Juventus FC & Serie A & Italy & Allianz Stadium & 11 \\
Liverpool FC & Premier League & UK & Anfield Stadium & 6 \\
Manchester City FC & Premier League & UK & Etihad Stadium & 5 \\
Manchester United & Premier League & UK & Old Trafford & 2 \\
FC & Ligue 1 & France & Le Parc des & 8 \\
Paris Saint-Germain & La Liga & Spain & Santiago Bernabéu & \multirow{2}{*}{ Stadium } \\
Real Madrid CF & & &
\end{tabular}

\subsection{Data Collection}

The data collected for this research comprised 400 text reviews written about each of the 10 European FCs' stadiums by visitors in the post-experience phase, for a total of 4000 reviews with 276,719 words. The sample was defined using non-random quota sampling [30] so that the collected reviews of each stadium were proportional in terms of traveller types and overall satisfaction ratings for each FC facility. The data were collected in 2020, and, following the example of previous studies [12,31], the sample included only reviews written in English.

All the Web reviews were gathered from Tripadvisor, the largest travel and tourism review platform [11], and compiled on a Microsoft Excel spreadsheet-one review per rowwhich was then converted into a .txt file. The dataset included the club's name, review title, review text, visitor's country of origin, overall satisfaction rating (i.e., measured on a 5-point scale) and traveller type based on Tripadvisor's categories (i.e., solo, business, couple, family and friends).

The visitors who wrote these reviews were extremely satisfied with their stadium visits as $90 \%$ rated their overall satisfaction as very good (4) or excellent (5). The reviewers came from 202 different countries-a wide diversity of nationalities that reflects football's globalisation. These guests were further grouped into regions. Most reviewers were from European countries (77\%), 10\% from North and Latin America, 9\% from Asia and 2\% from Africa and from Oceania. The visitors were also classified by how they travelled. Families made up $31 \%$ of the sample and $25 \%$ travelled with friends, while $24 \%$ were couples and $8 \%$ travelled solo. Only $2 \%$ were business visitors (Table 2 ). 
Table 2. Sample profile.

\begin{tabular}{ccccccccc}
\hline Rating & $\mathbf{N}^{\mathbf{1}}$ & $\mathbf{\%}$ & Traveller Type & $\mathbf{N}$ & $\mathbf{\%}$ & Country & $\mathbf{N}$ & $\mathbf{\%}$ \\
\hline 1 & 106 & $2 \%$ & Solo & 362 & $8 \%$ & Africa & 69 & $2 \%$ \\
2 & 78 & $2 \%$ & Business & 99 & $2 \%$ & Asia & 356 & $9 \%$ \\
3 & 261 & $6 \%$ & Couple & 1074 & $24 \%$ & Oceania & 93 & $2 \%$ \\
4 & 843 & $19 \%$ & Family & 1381 & $31 \%$ & Europe & 3088 & $77 \%$ \\
5 & 3112 & $71 \%$ & Friends & 1084 & $25 \%$ & America & 394 & $10 \%$ \\
\hline${ }^{1} \mathrm{~N}=$ number. & & & & & & &
\end{tabular}

\subsection{Data Analysis}

Content analysis of the 4000 Web reviews was conducted using Leximancer software. Leximancer has been utilised in different travel research contexts to identify the main narratives of visitors' experiences shared on social media platforms (e.g., [12,31,32]). The main advantage of carrying out content analysis with Leximancer is its automatic identification of the main themes within collections of natural language texts, with minimum intervention from the researcher [32]. Leximancer's tools suggest concepts based on word occurrence and word co-occurrence, using Bayesian statistical theory, nonlinear dynamics and machine learning algorithms.

Since Leximancer conducts both conceptual and relational analyses, it measures not only the presence of defined concepts in the texts analysed but also these concepts' interrelationships. This software organises and groups the concepts into themes, including how often they appear together in narratives. Leximancer's main output is concept maps made up of coloured circles containing concepts organised into themes. The concepts that appear most frequently together are placed nearer to one another on the concept map. The most prominent themes are given the warmest colours. As in previous studies, the present concept map's results were complemented by narrative analysis that identified segments of text focused on specific themes [33].

\section{Results}

\subsection{Overall Analysis}

The analyses revealed the existence of 15 themes: fan, tour, stadium, team, museum, room, staff, game, (best) place, ticket, seating, recommend(ation), food, shop and attraction (Figure 1 and Table 3 ). The following subsections discuss each theme in terms of its importance and main associations.

Table 3. Themes and concepts.

\begin{tabular}{|c|c|}
\hline Theme & Concepts \\
\hline Tour & $\begin{array}{c}\text { Tour }(\text { count }=3598, \text { relevance }=100 \%) \text {, guide }(1194,33 \%) \text {, audio (guide) }(503,24 \%) \text {, excellent }(\mathrm{menu}),(264,14 \%) \text {, } \\
\text { loved (experience) }(214,12 \%) \text { and virtual (reality) }(193,10 \%)\end{array}$ \\
\hline Stadium & $\begin{array}{l}\text { Stadium }(2865,88 \%) \text {, home }(880,48 \%) \text {, view }(605,17 \%) \text {, ground }(483,26 \%) \text {, inside }(436,15 \%) \text {, full (capacity) (401, } \\
14 \%) \text {, top }(373,14 \%) \text {, huge (stadium) }(331,12 \%) \text {, design }(221,10 \%) \text {, impressive (facility) }(203,13 \%) \text { and tourists } \\
(201,12 \%)\end{array}$ \\
\hline Team & $\begin{array}{l}\text { Team }(1021,50 \%) \text {, day }(821,17 \%) \text {, amazing (experience) }(590,15 \%) \text {, fantastic (place) }(372,12 \%) \text { and famous } \\
\text { (player) }(333,11 \%)\end{array}$ \\
\hline Museum & $\begin{array}{c}\text { Museum }(1783,46 \%) \text {, club }(939,26 \%) \text {, history }(670,17 \%) \text {, learn (ing experience) }(602,15 \%) \text {, feel(ing) }(313,14 \%) \text {, } \\
\text { booked (tour) }(207,10 \%) \text { and trophies }(200,10 \%)\end{array}$ \\
\hline Fan & Fan $(1454,40 \%)$, visit $(1422,40 \%)$, football $(1231,34 \%)$ and experience $(909,25 \%)$ \\
\hline Room & $\begin{array}{l}\text { Room }(1002,32 \%) \text {, picture }(892,24 \%) \text {, press }(851,18 \%) \text {, pitch }(520,19 \%) \text {, dressing (room) }(486,18 \%) \text {, favourite } \\
\text { (place) }(411,12 \%) \text {, (pictures) take(n) }(463,13 \%) \text {, photos }(513,12 \%) \text {, tunnel }(378,15 \%) \text {, walk }(334,12 \%) \text {, area (300, } \\
11 \%) \text { and excellent (experience) }(244,10 \%)\end{array}$ \\
\hline Staff & Staff $(823,23 \%)$, friendly (staff) $(589,16 \%)$, enjoy (able time) $(537,15 \%)$ and interesting (information) $(386,11 \%)$ \\
\hline Game & $\begin{array}{c}\text { Game }(1036,33 \%) \text {, atmosphere ( } 736,20 \%) \text {, watch (ing matches) }(316,12 \%) \text {, emotions }(214,13 \%) \text {, beautiful } \\
\text { (emotions) }(200,11 \%) \text { and return }(198,10 \%)\end{array}$ \\
\hline
\end{tabular}


Table 3. Cont.

\begin{tabular}{cc}
\hline Theme & Concepts \\
\hline (Best) place & Place $(720,21 \%)$, world $(651,19 \%)$, best (place) $(415,15 \%)$ and arena $(231,11 \%)$ \\
\hline Ticket & Ticket $(658,19 \%)$, (things to) buy $(458,15 \%)$, outside (booth) $(190,10 \%)$ and access $(189,10 \%)$ \\
\hline Seating & Seating $(455,15 \%)$, people $(285,12 \%)$, league $(255,11 \%)$, champions $(225,11 \%)$ and minutes $(197,10 \%)$ \\
\hline Recommend(ation) & Recommend (ation) $(784,22 \%)$ and money $(216,10 \%)$ \\
\hline Food & Food $(329,12 \%)$, drink $(209,10 \%)$, restaurant $(202,10 \%)$, bar $(201,10 \%)$ and meal $(199,10 \%)$ \\
\hline Shop & Shop $(341,12 \%)$, memories $(296,11 \%)$, souvenir $(199,10 \%)$ and merchandise $(197,10 \%)$ \\
\hline Attraction & Attraction $(198,10 \%)$ and magical (experience) $(196,10 \%)$ \\
\hline
\end{tabular}

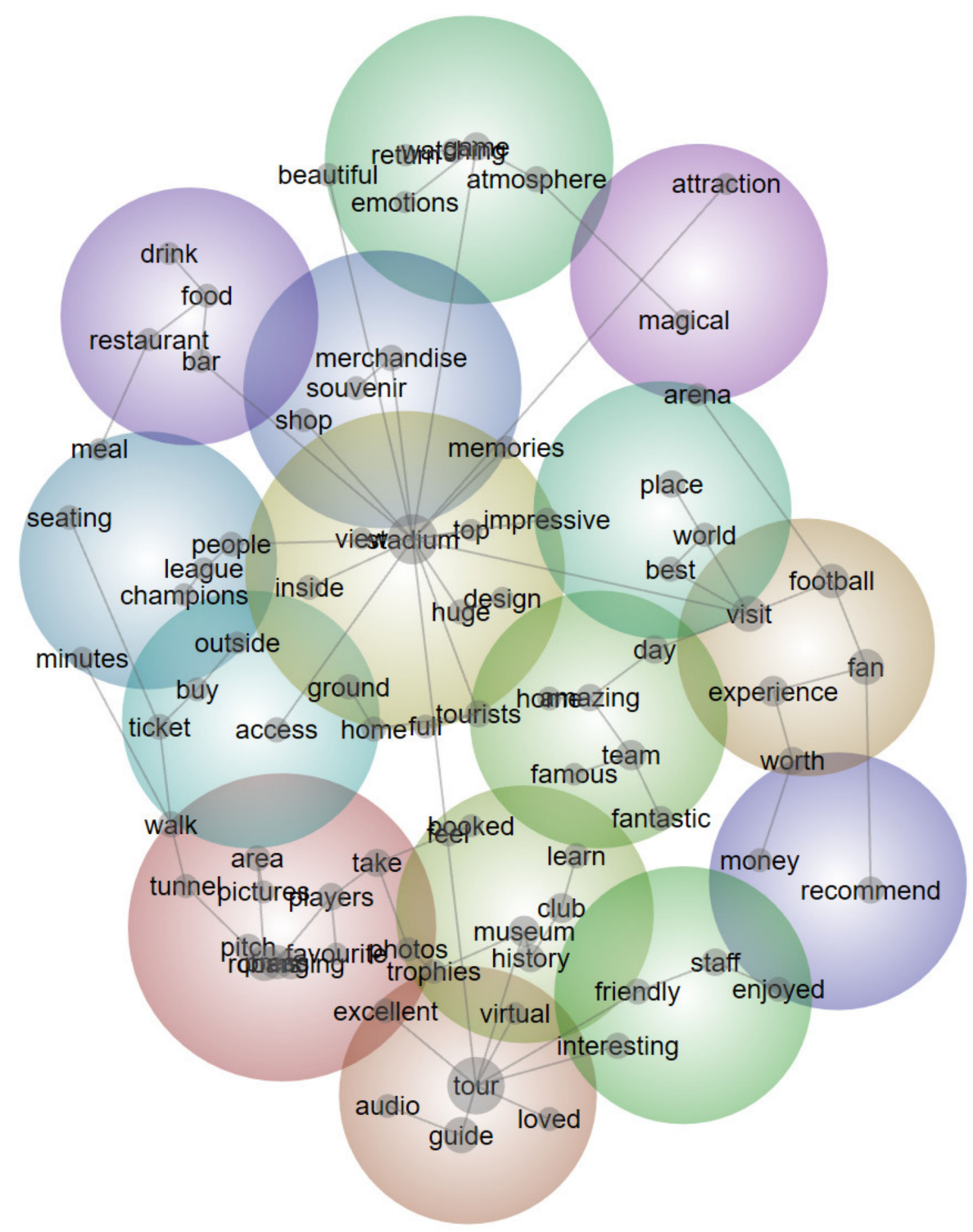

Figure 1. Concept map generated.

\subsubsection{Tour}

The tour theme encompasses the concepts of tour (count $=3598$, relevance $=100 \%$ ), guide $(1194,33 \%)$, audio (guide) $(503,24 \%)$, excellent (menu), $(264,14 \%)$, loved (experience) $(214,12 \%)$ and virtual (reality) $(193,10 \%)$. This theme describes the main tour services 
offered, namely, the guided tour, audio tour and, in some stadiums, virtual reality tour. The tour guides' role is also highlighted within this theme.

The visitors frequently associated the words 'excellent' and 'love' with tours. A reviewer wrote, '[this was an e]xcellent tour. The tour and visit to the stadium exceeded my expectations. I loved every minute of it' (team: Juventus FC, nationality: $n / a$, overall rating: 5, traveller type: friends). Another visitor commented, '[we enjoyed our t]our [g]uide. This was a treat for the whole family and we loved it' (stadium tour $=$ Manchester United FC, nationality $=\mathrm{UK}$, overall rating $=5$, traveller type $=$ family).

Regarding guided tours and tour guides, one review read:

[This was a w]onderful [b]irthday [e]xperience. Luis was our tour guide, and he was a gentleman. He made my son feel special, along with the other birthday boy on the tour, and his knowledge and humour really gave an already amazing tour that bit extra. (Chelsea FC, UK, 5, family)

Another review stated, '[A s]pecial thanks [goes] to our tour guide Jaime who had plenty of details and stories to tell and with humour made the whole experience very special!'(Chelsea FC, France, 5, family).

With regard to the audio guide, a visitor shared:

[It was f]antastic [to m]eet a [1]egend and [take the] self[-]guided tour. The audio guide was easy to follow, with an excellent menu to follow. There were numbered signs placed around the ground as you follow the route at your own pace and there are helpful and knowledgeable stewards all along the route to help. (Liverpool, UK, 5, solo)

Another British guest wrote:

So the Emirates Stadium offer[s] different types of tour. I did the 'legends' tour which is hosted by one of several great players of the past[.Y]ou know which legend will be hosting at the time of booking. In our case, the host was Charlie George (scorer of the winning goal in the 1971 FAC [Football Association Challenge] Cup final) in Arsenal's first 'double'. (Arsenal FC, UK, 5, friends)

Concerning virtual reality experiences, a reviewer said:

[The tour was r]eally interesting and atmospheric. [The stadium is a] place not to miss out [on] when travelling to this city. [as it is] very interesting and I especially enjoyed the virtual reality experience at the end. (FC Barcelona, UK, 5, family)

Another visitor reported, '[w]e did have a virtual reality Pep Guardiola in the press conference room and you were allowed to sit in his chair when the international and UK media fire questions at him' (Manchester City, UK, 5, solo).

\subsubsection{Stadium}

The stadium theme combines the concepts of stadium (2865, 88\%), home $(880,48 \%)$, view $(605,17 \%)$, ground $(483,26 \%)$, inside $(436,15 \%)$, full (capacity) $(401,14 \%)$, top (373, $14 \%)$, huge (stadium) $(331,12 \%)$, design $(221,10 \%)$, impressive (facility) $(203,13 \%)$ and tourists $(201,12 \%)$. Various football fans highlighted that the stadium they visited is the home of a top football team. For instance, a guest wrote, ' $[\mathrm{m}] \mathrm{y}$ wife gave me this tour as a birthday gift in New Zealand. Arriving in London I was looking forward to having a look around the home of my favourite EPL [European Premier League] team' (Chelsea, New Zealand, 5, couple). Another visitor shared, '[i]t was an interesting experience standing in [sic] the home ground of one of the most famous and top soccer team[s] in the world' (FC Barcelona, Singapore, 5, friends).

One review also mentioned the stadium's design and architecture:

The Allianz Arena is the home ground of Bayern Munich FC. It is still a quite new stadium. The external view is splendid, like a[n] outer space ship. At night it has lights of different colors to give it an amazing scene [sic]. Normally it is in red which is Bayern Munich's home color. The design of the stadium is quite good and from different sections, you can still watch the game without [any] obstruction. (FC Bayern Munich, China, 4, solo) 
Another review stated, 'it was designed by star architects Herzog \& Demeuron. [I n]ote[d] the outer skin that can change the color of its lights' (FC Bayern Munich, Germany, 5, friends).

According to visitors, tours offer views from both outside and inside the facilities. A visitor reported:

The huge stadium was very impressive and gigantic and it has became [sic] one of the key sites [to visit] in Madrid. Many visitors, especially foreign tourists came [sic] by here to take photographs. One can book a guided tour inside the stadium where you [sic] will be brought to the various 'important' places (i.e., rooms) where your favourite soccer players like Cristiano Ronaldo attended briefing[s] or changed his attire[,] etc. (Real Madrid FC, Singapore, 3, couple)

Still another visitor wrote:

The stadium is imposing, [and it] easily dominates the immediate area[. O]n our visit[,] there were several coach loads of tourists visiting the stadium[. I]t is a really popular tour but as Real Madrid are one of the most well supported teams in the world [this is] hardly surprising really. (Real Madrid FC, UK, 5, friends)

\subsubsection{Team}

The team theme comprises the concepts of team $(1021,50 \%)$, day $(821,17 \%)$, amazing (experience) $(590,15 \%)$, fantastic (place) $(372,12 \%)$ and famous (player) $(333,11 \%)$. The narratives linked with this theme highlight the teams and their famous players' role.

One visitor said, 'PSG [Paris-Saint Germain] is the team of the moment [with] star players everywhere, [and] newer ownership that is prepared to spend big money[,] etc.' (Paris Saint-Germain, Australia, 5, couple). Another guest shared, '[w]e were very proud of its [FC Barcelona] Hungarian football player: László Kubala. He was one of the most famous footballer[s] in the team. His statue is in front of the stadium' (FC Barcelona, Hungary, 4, friends). Yet another visitor wrote, '[this is] the best team and the best players! [I was v] ery grateful [to] see Messi the GOAT [sic] playing! (FC Barcelona, UK, 4, solo). A further review read:

[This b]eautiful stadium contains the White Black spirit and the determination of a team that plays a crazy game. [T] he arrival of Cristiano Ronaldo pushed me to come to Italy and take a trip to Italy. (Juventus FC, US, 5, solo)

\subsubsection{Museum}

The museum theme includes the concepts of museum $(1783,46 \%)$, club $(939,26 \%)$, history $(670,17 \%)$, learn(ing experience) $(602,15 \%)$, feel(ing) $(313,14 \%)$, booked (tour) (207, $10 \%)$ and trophies $(200,10 \%)$. The reviews containing this theme emphasised trophies' importance and placed value on experiences of learning about the clubs' history.

A guest urged readers to '[v]isit the museum and see our club[']s history in shirts, boots, trophies, memorabilia, videos and of course all the trophies' (Chelsea FC, UK, 5, family). Another visitor observed, '[t]he museum is awash with trophies and it[']s interesting reading the history of the club from [the] early days right up to Messi's golden boot display' (FC Barcelona, US, 4, solo). One reviewer further highlighted technological experiences in the museum, stating that ' $\mathrm{t}$ ] he J[uventus] Museum is as well very impressive both [in terms of] content and technological aspect[s]. You could spend hours [there] if you were to view all [the] interactive screens' (Juventus FC, China, 5, couple).

Other visitors highlighted the learning experiences provided during museum visits. One review read:

[I d]id a museum and stadium tour. It was great to learn about the history of FC Barcelona and see the stadium up close. The museum discusses previous coaches and players, shows old shirts and trophies and explains the connection between the city and the club very well. (FC Barcelona, South Africa, 5, solo)

A guest reported that '[s]ee[ing] the museum with all [t]he Bayern [h]istory was a great learning experience' (FC Bayern Munich, US, 5, couple). Another reviewer said, 'I 
liked it! [The museum shows the v]ery interesting history of the club. [This m] useum inspired me to read more at home' (FC Barcelona, Poland, 4, couple).

\subsubsection{Fan}

The fan theme includes the concepts of fan (1454, 40\%), visit (1422, 40\%), football (1231, $34 \%$ ) and experience $(909,25 \%)$. This theme covers different market segments' experiences of visiting football stadiums, which reflect the visitors' level of involvement in football or the teams (e.g., team fans, football fans and even those who are not fans).

A reviewer shared:

[We attended the] Champions League game against Juventus. We may have lost the game, but visiting Old Trafford for the first time since I first became a United fan at age 5 , and getting to watch Ronaldo return home, on my birthday no less, was a childhood dream come true. (Manchester United FC, Singapore, 5, friends)

Another visitor commented:

[This was a g]reat [v]isit to the home of Bayern Munich. I am a huge Bayern Munich fan so this visit was like going to the mecca of football. [This is a] must go for all football fans even if you don't support [the] Bayern team. (FC Bayern Munich, US, 5, couple)

A guest wrote, '[s]o I would recommend this for the general football fan as well as City fans[. I] gives a carefully curated but fascinating insight into how a modern super professional [FC] operates' (Manchester City FC, UK, 5, family).

\subsubsection{Room}

The rooms theme contains the concepts of rooms $(1002,32 \%)$, picture $(892,24 \%)$, press $(851,18 \%)$, pitch $(520,19 \%)$, dressing (room) $(486,18 \%)$, favourite (place) $(411,12 \%)$, (pictures) take(n) $(463,13 \%)$, photos $(513,12 \%)$, tunnel $(378,15 \%)$, walk $(334,12 \%)$, area (300, 11\%) and excellent (experience) (244, 10\%). The visitors valued being in the same places as the team and players (e.g., the dressing room, tunnel and dugout) and other sections, such as the VIP area and press room. Various reviews highlighted the opportunity to get a real look at all the behind-the-scenes facilities, to walk where the players do and to take photographs.

One visitor said:

[This was a g]reat experience and [the place is full of] atmosphere. [We d]id the stadium tour which was incredible[,] looking through the history of the club and experiencing [looking] behind the scenes [at] the changing rooms, [and] tunnel and getting pitch side was incredible[. You] get an idea of how big the stadium is from the players['] perspective. (FC Barcelona, UK, 5, friends)

Another guest wrote, '[w]e got the gist of what was happening and it was great to see behind the scenes, [such as] the treatment room, [and] dressing rooms, [as well as] go on the pitch[. It was] really great' (Juventus FC, UK, 5, family). A related review stated, '[t]he stadium tour is a look behind the scenes as you walk through the stadium, locker room, VIP area, etc. and get a feel for the team, the history and their fans' (Manchester United, US, 5 , friends).

Still another reviewer reported, '[w]e went pitch side, through the press conference room, in both dressing rooms and through the tunnel - just like the players do' (Chelsea FC, UK, 5, couple). One review read:

We visited the changing rooms where each shirt was hung up, the massage room and the bath[. W]e walked through the tunnel to the pitch and got to sit in the managers seat at the side of the pitch [and] also sit on the press conference table which was all amazing! My son tho]roughly enjoyed it[. H]e was grinning from ear to ear! (Chelsea FC, UK, 5, family)

\subsubsection{Staff}

The staff theme includes the concepts of staff $(823,23 \%)$, friendly (staff) $(589,16 \%)$, enjoy(able time) $(537,15 \%)$ and interesting (information) $(386,11 \%)$. The visitors specifically wrote about the staff, their skills and the ways they contributed to positive tour experiences. 
A guest commented, '[the] staff were very informative and friendly and open to any questions, so all in all I loved every second' (Chelsea FC, UK, 5, couple). Another visitor extolled the tour as '[a]wesome. [This was our f]irst time at Anfield — best day ever! [The s]taff are super helpful, [and] happy and all were full of smiles. [This is a f]antastic place' (Liverpool FC, UK, 5, friends). One reviewer reported, '[a]ll the staff were knowledgeable and friendly and offered to take photos of us at all points!' (Chelsea FC, UK, 5, friends).

An enthusiastic guest exclaimed:

We Love You Liverpool We Do! [sic] I booked your tour for my boyfriend['s] birthday and we were definitely not disappointed! All of the staff on the grounds are lovely, [and] local, [and] give you the best [i]nformation about the club[. I]t is just like a big happy family! (Liverpool, UK, 5, couple)

Another relevant review stated, '[t]he organisation at the venue is second to none fantastic, friendly security staff who will help you every step of the way' (Manchester City, $\mathrm{UK}, 5$, couple).

\subsubsection{Game}

The game theme encompasses the concepts of game (1036, 33\%), atmosphere (736, $20 \%$ ), watch(ing matches) $(316,12 \%)$, emotions $(214,13 \%)$, beautiful (emotions) $(200,11 \%)$ and return $(198,10 \%)$. One visitor shared, '[the tour was a]mazing. T[his is t]he most amazing, impressive, beautiful, full [of] spirit and smiles stadium ever. And [the] football game [was] memorable' (Juventus FC, Austria, 5, friends). Another visitor said:

I always return very willingly, and every time this stadium knows how to give me beautiful and unique emotions. I will definitely return again, both to cheer on my favorite team (Juventus), and to watch the matches played by Italy, [as this is] the Allianz Stadium, one of the main stadiums that host the Italian national football team's home games. (Juventus FC, Italy, 5, friends)

\subsubsection{Place}

The place theme includes the concepts of place $(720,21 \%)$, world $(651,19 \%)$, best (place) $(415,15 \%)$ and arena $(231,11 \%)$. Guests even describe their stadium tour experiences as visiting the best place on the planet.

A visitor wrote, '[this was a] DREAM COME TRUE [sic]. This place is nothing [less than] the best place in the world after your home' (FC Barcelona, United Arab Emirates, 5 , friends). Another reviewer asserted, '[this is the b]est place on the planet' (Manchester United FC, Spain, 5, family). A review read:

[This was o]ne of the best trips I [have] ever took [sic]. I could talk [for] hours and hours about this place that left me with a huge smile and admiration for the unique, second to none accomplishments of the best [FC] in the world. (Real Madrid FC, US, 5, family)

One guest declared that this is '[t]he best place in Munich for sport lovers, especially for FC Bayern Munich fans. This is the place of their dream' (FC Bayern Munich, Albania, 5 , couple).

\subsubsection{Ticket}

The ticket theme combines the concepts of ticket $(658,19 \%)$, (things to) buy $(458,15 \%)$, outside (booth) $(190,10 \%)$ and access $(189,10 \%)$. This theme is mainly related to access to the stadiums and ticket purchases.

A satisfied guest said:

We got tickets for [the] VIP [area] and the treatment was royal!!! [It has an u]nbelievable restaurant, [and] the VIP rooms are extremely nice and [enclosed] in glass. The food, minibar, strawberries, [and c] hampaign [sic] [were great] but all together [th]is stadium is worth visiting also on non-game day[s]. (Juventus FC, Croatia, 5, friends)

Another visitor reported, '[it was e]asy to buy tickets, [as the] metro access [was] just perfect, [and the] organization (including polite security) was fantastic' (Paris SaintGermain, US, 5, friends). One review suggested: 
If you have time in Paris, you can buy it [a ticket] at the stadium or the official shop on the Champs-Elyse[e]s. The Champs-Elysees store sells replicas of uniforms on the first floor, and you can buy tickets on the second floor. (emphasis in original) (Paris Saint-Germain, Japan, 5, solo)

A visitor observed, '[w]e booked the tour for our disabled son[']s 21st birthday. We were really impressed with the accessibility of the tour as our son is a wheelchair user' (Chelsea FC, UK, 5, family). Another guest wrote, '[d]isabled visitors [have] no problem[s as] lifts [are] available to those who need them. Congratulations LFC' (Liverpool, UK, 5, couple). One reviewer stated, '[w]e purchased tickets on [the] Real Madrid site and used [our] mobile wallet for ticket entry with no problems' (Real Madrid FC, UK, 5, couple). Still another reviewer asserted, 'I brought [sic] tour tickets as a Christmas present for my brother and the tour did not disappoint' (Chelsea FC, UK, 5, friends).

\subsubsection{Seating}

The seating theme comprises the concepts of seating $(455,15 \%)$, people $(285,12 \%)$, league $(255,11 \%)$, champions $(225,11 \%)$ and minutes $(197,10 \%)$. The visitors talk about seats in their reviews, including seating for people with disabilities and having the opportunity to sit in the same place as football players.

A guest shared, '[t]here is room for 100,000 people! We saw [the] Barcelona vs Chelsea champions league match 2018' (FC Barcelona, Denmark, 5, friends). Another visitor said, '[i]t is a beautiful stadium with an amazing atmosphere, design and fantastic seating arrangements' (FC Bayern Munich, US, 5, solo). Regarding seating for people with disabilities, a reviewer wrote:

Wheelie chair users [are] treated like VIPs outside and inside the stadium. [The s]eating view [was] out of this world[. We] spoke to at least 10 staff [members] from [the] car park to [the] waitress service at our seats, [who were] all polite and respectful and even offered to take photos. We are the best club in the world. YNWA [You'll never walk alone]! (Liverpool FC, UK, 5, family)

One guest reported:

It has been a great experience!!! You can take the pictures that you want, [and] you can visit [the] home team change room, [sit] in the same place [as] Arsenal players, in the president['s] chairs, [or] in the post[-]match conference press [room] and take pictures on your own without any restriction! (Arsenal FC, Spain, 5, family)

\subsubsection{Recommend(ation)}

The recommend(ation) theme unites the concepts of recommend(ation) $(784,22 \%)$ and money $(216,10 \%)$. One visitor stated, '[the t]our is brilliant [and e]xcellent value for money. W[e w]ould highly recommend [it as w]ell worth a visit for all the family. It was a great day and well worth the money, [so] I definitely would recommend [it]' (Chelsea FC, $\mathrm{UK}, 5$, family). Another reviewer asserted, '[t]he entire tour was breath[-]taking. [I would d] efinitely recommend [it]! This is [sic] a life changing experience for me' (Manchester City FC, Canada, 5, solo). A visitor said, '[this was a b]irthday visit for my daughter. [The tour is h]ighly recommended and good value for money' (Arsenal FC, UK, 4, family).

Guests also shared that they were willing to come back and recommended either taking another stadium tour or coming on a non-match day. A review read, 'I would highly recommend the stadium and museum tour. [I am h]oping to be able to catch a match there in the near future!' (Manchester United, UK, 5, friends). Another visitor wrote, '[I w]ould recommend [the tour] and [we] will be visiting again with our free annual passes. [This was a b]rilliant day out!!!' (Manchester United, UK, 5, family).

\subsubsection{Food}

The food theme includes the concepts of food $(329,12 \%)$, drink $(209,10 \%)$, restaurant $(202,10 \%)$, bar $(201,10 \%)$ and meal $(199,10 \%)$. Food is considered an important component of stadium tour experiences by different traveller types. 
One guest enthused:

We attended a charity event in the Anfield stadium[']s events facility which was situated on the top floor. The room was filled with well decorated tables and fantastic staff who catered for our needs [The f]ood was served as a three course meal and was cooked very well[. I]t was $5^{*}$ service at a $5^{*}$ facility. [This is a g]reat venue for events and parties! [It is highly r]ecommended. (Liverpool FC, UK, 5, business)

Another visitor maintained that:

[The stadium] also has a lovely cafe and restaurant where lovely drinks and mini desserts [are offered]. We got the white chocolate Nutella and Oreo [c]repe[, which] was so good [and came] with a lovely view of the green pitch. (FC Barcelona, UK 5, couple)

A reviewer noted, '[w]e had a package which included a 2 course lunch at Frankie['s] [S]ports [B]ar. The food here was delicious and [came in] a good portion size' (Chelsea, UK, 5 , friends).

\subsubsection{Shop}

The shop theme comprises the concepts of shop (341, 12\%), memories $(296,11 \%)$, souvenir $(199,10 \%)$ and merchandise $(197,10 \%)$. This theme describes retail experiences in merchandise and/or fan stores located in the stadiums.

One guest wrote, '[t]he gift shop is very expensive but it is a once in a lifetime [opportunity] (at least for me) so it [is] worth it' (Manchester United, UK, 5, family). Another visitor reported, 'the shop is a retail experience in itself!!' (Barcelona FC, UK, 5, friends). A visitor observed, 'the club shop is the best I have ever seen [and] the amount of merchandize [sic] on display over [sic] three floors is huge' (FC Barcelona, US, 4, solo). A reviewer stated, '[n]ot To Mention The Gift Shop Would Be A Crime [sic]. [I w]ill Be Back For More [sic]' (FC Barcelona, India, 5, couple).

Various visitors highlighted that the store offers gifts for different consumers, such as adults, kids and those shopping for different occasions (i.e., to remember that day or for use in daily life). A guest recommended 'spoil[ing] yourself at the fan shop with almost anything that you would think you need for your home/office/car/etc. [sic] [Y]ou will find it [t]here with [the] Bayern logo!!! I mean it! Everything [is there]!' (FC Bayern Munich, Canada, 5, couple). Another visitor said, 'then we finished with the Megastore, [and] a shopping spree with every [m]omaribilia [sic] thing [possible] with Bayern [on it]' (FC Bayern Munich, Malta, 5, couple). A review read, '[p]ost tour we decamped to the official Juventus shop where there was plenty of Juventus stuff to buy. I left much poorer but with 2 very happy kids!' (Juventus FC, UK, 5, family). Another reviewer reported, 'I a]ccompanied my son who had a birthday voucher. [I r] ecommend [getting] nice souvenirs to remind you of the day' (Chelsea FC, UK, 4, family).

Other guests talked about photographs and certificates. A visitor observed that, '[a]t the end of the tour[,] you exit through the gift shop, where you can purchase your photos and print out a certificate to say that you've visited the stadium (i.e., free certificate)' (Manchester United, Spain, 5, family). One reviewer noted, '[t]he [f]an shop has a great collection and we took some nice pictures where they photo shopped us with the players' (FC Bayern Munich, Germany, 4, couple).

\subsubsection{Attraction}

The attraction theme combines the concepts of attraction (198, 10\%) and magical (experience) $(196,10 \%)$. The narratives that included this theme describe stadium visits as a tourist attraction and an opportunity to enjoy a magical place. A guest shared, ' $[\mathrm{w}] \mathrm{ith}$ a soccer player in the family, this was a must-see attraction and gave our family a break from the downtown London scene' (Chelsea FC, UK, 5, family). Another visitor wrote, 'I would definitely recommend this tour to all football fans, especially City fans, but I would recommend it to others who are looking for [a] different type of attractions to visit, in addition to the usual cathedrals and museums' (Manchester City, Canada, 5, couple). 


\subsection{Analysis by Ratings}

Visitors who evaluate their overall satisfaction with stadium tour experiences as excellent (i.e., 5 out of 5 points) or as terrible or poor (i.e., 1 or 2 out of 5 points) share different content in Web reviews. The rating analysis' results show that visitors who give stadium and museum tours a 5 more frequently share narratives with concepts related to emotions (likelihood $=89 \%$; theme $=$ game), loved (experience) $(78 \%$, tour), feel(ing) ( $73 \%$, museum) and enjoy(able time) $(70 \%$, staff). This group of more satisfied visitors is more likely to use the concepts of amazing (experience) $(88 \%)$, memories $(88 \%)$, fantastic (place) (87\%), magical (experience) (82\%) and excellent (experience) $(78 \%)$. As expected, this group is more inclined to recommend (79\%) tours and visits and exhibits intentions to return $(76 \%)$. The group that assigns lower overall satisfaction ratings ( $4 \%$ of the total sample) is more likely to write about negative value-for-money assessments and use the concepts of money $(11 \%$, recommend[ation]), people ( $10 \%$, seating), souvenir $(9 \%$, shop) and food ( $9 \%$, food).

\section{Discussion}

This study sought to answer one research question: What are the main narratives shared online about - and the dimensions of-visitors' experiences of top football brands in stadium tours? The research was based on a content analysis of Web reviews posted by 4000 guests of 10 top European football stadiums.

The analysis identified 15 major themes: tour, stadium, team, museum, fan, rooms, staff, game, (best) place, tickets, seating, recommend(ation), food, shop and attraction. The tours are the core service, which visitors associate with the concepts of excellence and love. The associated narratives mention different types of tours: Self-guided audio, virtual reality and guided tours. The tour guides are of utmost importance, and many visitors include their names in reviews. The weight given by visitors to professional guides has been confirmed by previous studies of daily tours (e.g., [20]). Tour guides share the stadiums' history and heritage [7], manage the tours, have contact with participants and make the entire experience special. The present results also reveal that guests see virtual reality elements as complementing their experiences, but these components do not relegate personal contact with tour guides to a second place. Instead, virtual reality is perceived as an add-on to the holistic experience visitors can get when they visit football stadiums.

The stadium theme comprises not only stadiums' main tangible characteristics (e.g., dimensions, frontage and general architectural design) but also an intangible dimension as the perceived 'home of the team'. The tangible components can be viewed as branding assets [5], providing evidence that the stadiums' construction is of utmost importance to sport enthusiasts [7] because it is linked with fans' identity [34]. In addition, the stadiums are considered more than just a building or facility. They have a 'religious significance' [9] involving a strong sentimental meaning because stadiums are regarded as the teams' home $[5,7]$.

The team theme is linked with famous football stars who play or have played in each stadium. Legends, heroes and international players are identified as three of the main stories in contemporary FC museums-a conclusion that is in line with Appel's [1] research. Thus, museums pay special attention to teams' stars, displaying their achievements as players and, quite often, as citizens.

Museums are visited during stadium tours so that visitors can explore different dimensions of the FC in question. Museums are also a dimension of the DAILYSERV scale [20]. In the current study's findings, the museum theme is associated with physical components, memorabilia (e.g., trophies and shirts worn in important games) and heritage exhibitions. Guests also report that technological devices in these institutions, such as interactive screens, enhance already enjoyable experiences. The narratives conveying this theme are further linked with education [1] since museums are perceived as a major opportunity to learn about the clubs' history. 
The fan theme is reflected in narratives addressing two main ideas. The first is that stadiums and their museums must be visited by everyone, that is, not only club fans but also other football enthusiasts and even tourists in general. This narrative is in accordance with Gammon and Fear's [8] conclusion that stadium tours can attract both football fans and non-fans. According to Yang [2] (p. 1880), football museums 'construct a collective identity for football enthusiasts irrespective of age, ability, gender or nationality'. The second narrative connected to this theme is that fans themselves can be viewed as 'live exhibits' based on fan memorabilia. This perspective was clearly expressed by Yang [2] (p. 1875), who stated:

Fans become 'live' exhibits and provide information about their own football teams, their football heroes, and the culture of football supporting [groups]. Supporters are an essential element of the football history of the football being showcased[. T] here are also visitors who live and breathe the history of football.

The rooms theme covers the experience of visiting the stadiums' authentic backstage areas such as press and dressing rooms. This theme is also quite significant because it highlights the opportunities offered to visitors to experience the stadiums from their heroes' point of view [8]. In other words, guests become themselves the 'stars' at least for a few moments.

The staff theme is associated with narratives about front office staff other than the tour guides. The associated narratives concur with the dimension of responsiveness included in the HISTOQUAL scale [21].

The game theme comprises narratives related to the recreation of emotions generated by games and the stadiums' atmosphere as these places are where unique, unforgettable moments of the clubs' history have taken place. Along these lines, stadium tours tend to offer different types of game experiences (i.e., frequently based on virtual reality technology) giving the impression of what a live game is like [15].

The place theme includes narratives that classify the stadiums as the best place in the relevant country or even on the planet. This theme is in accordance with Bale's [9] classification of stadiums as beloved places with significant social meaning. Stadiums are seen as facilities that create powerful feelings of adoration [8]. Most of these issues are clearly related to the stadium theme mentioned previously.

The tickets theme is mainly linked with access to the stadiums and entrance ticket purchases. This topic has to do with not only experiences' quality but also the clubs' financial return. First, the act of buying a tour ticket is often the first point of contact, which means that it can affect guests' perceptions of the entire experience from the beginning. Second, the different types of tours - ranging from the cheapest to premium tickets - are selected for in the ticket office. Regarding access, the narratives with this theme provide support for the idea that football museums' value proposition is 'football for all' [2], which includes coping with visitors with disabilities. Convenience is also a service quality dimension of Cheng and Wan's [21] HISTOQUAL scale and Su and Teng's [11] study.

The seating theme can be understood as a tangible component of stadium tours [11]. Guests might have an opportunity to see what the stadiums look like on non-match days [1]. This theme involves seating in different parts of the stadiums and in the presidential box and the supreme experience of sitting in the same chair used by the head coach.

The recommend(ation) theme reflects positive post-purchase behaviour. The visitors who write online reviews expressing their satisfaction with stadium visits not only recommend the tours to others but also share their intention to return to the stadiums.

The food theme describes different visitor segments' food and beverages experiences at the stadium's restaurant and coffee shops (e.g., VIP tickets and packages with meals and snacks during tours). Previous studies have also highlighted the role of food in daily tours [20] since food is considered a part of the consumables dimension of museums' service quality [11].

The shop theme is associated with narratives about experiences in stadiums' merchandise stores during tours. Shopping facilities is also a dimension of the DAILYSERV 
scale [20]. These facilities also fall within the consumables dimension of museums' service quality [11]. However, FC souvenirs can become part of the guests' personal life [2] because shops offer unique retail experiences and visitors view them as part of the stadiums' tourism infrastructure [7]. In other words, walking around in and buying items from FC museum shops are experiences that cannot be separated from the rest of the tour.

Finally, the attraction theme is mainly linked with narratives that describe the stadiums as a tourist attraction. This theme is in accordance with previous studies that have classified football stadiums as part of local heritage [8], tourism landscapes [7], city tourism attractions [5] and entertainment venues [14] that become part of cities' cultural itineraries [19]. The use of the term 'tourists' reveals that football stadium museums benefit from football's international appeal as a global industry [2].

Most of the research conducted so far has analysed stadium tours from a supplyside perspective (cf. $[5,7,8]$ ). The present study's main contribution to the literature is an in-depth understanding of stadium experiences on non-match days from the visitors' perspective. This research offers significant and novel conceptual contributions that can be divided into two main categories.

First, the current results are a significant contribution to the literature on service quality in daily tours [20] and museums (e.g., [11,21,22]) given the new research context under study: football stadium museum and facility tours. Compared with the DAILYSERV's museum and sites dimensions, the present research revealed more complex experiences involving the museum theme and other themes related to the stadiums' frontstage (i.e., general architecture and seating) and backstage (i.e., rooms) areas. In contrast to the scales developed to evaluate museums' service quality (cf. [11,21,22]), the current study's results suggest that the consumables dimension of stadium tours need to be replaced by two different retail experiences related to the food and shop themes.

Second, the comprehensive and holistic character of visits to football stadiums and museums means these tours include not only diversified physical places but also different experiences at distinct moments in time. People visiting stadiums link their tours to past experiences related to the clubs' historic moments and even to future experiences linked to these guests' expectations of the teams' continued performance. Stadium and museum tours allow FCs to maximise venues' use, thereby contributing to these clubs' economic sustainability while offering memorable experiences that become the basis for fans' engagement and co-creation.

The emotional nature of visits to football stadiums and museums provides evidence of the central place occupied by fans in this context. To a limited extent, these tours can be labelled a 'virtual emotional reality' as opposed to a 'virtual (technological) reality'. While tours are partially based on simulated experiences created or augmented by technology, the former reality is generated by immersing visitors in deep emotional experiences that cause them to experience a kind of dream filled with strong sentimental feelings. This component is particularly evident in prominent themes such as stadium, rooms, seating, place and team.

This study's findings have two major managerial implications for sport stadium managers. These are briefly discussed in the subsections below.

Football stadiums and museums' visitors look for unique, memorable moments that complement their experiences as football fans-even if they are not fans of the FC stadium they are touring. According to the content analysis's results, the main themes in the narratives shared online are linked with the core service (tour and museum themes), the backstage (rooms) and frontstage (stadium and seating) areas, history (game, places and team), convenience (tickets), retail experiences (food and shop), people (staff and fan), city (attraction) and post-purchase behaviour (recommendation). Managers must, therefore, develop a variety of tours that encompass these different elements in order to integrate past experiences and future expectations so that guests have strong emotional experiences.

Managers should also use Web reviews to identify guests' overall level of satisfaction and areas needing improvement based on the narratives shared online. This study was 
based on thousands of Web reviews posted by visitors to FC stadiums' tour and museum. These reviews are a major source of data that can contribute relevant information about the service quality provided and facilitate extremely significant benchmark analysis of what the competition is doing.

This research's main limitation is linked to the data collection method. As data from Web reviews were used, only visitors who shared their experiences online were included in the analysis. Online reviews may also underrepresent some types of travellers (e.g., moderately satisfied visitors). Future studies could avoid this problem by developing a new scale to measure service quality perceptions of sport stadium and museum tours based on primary data collection methods (e.g., surveys). Another area that merits further research is stadium tour experiences in a post-COVID-19 scenario to test whether the themes remain the same.

Author Contributions: Conceptualisation, A.B. (Ana Brochado), C.B. and A.B. (Adrien Bouchet); methodology, A.B. (Ana Brochado) and F.O.; software, F.O.; validation, A.B. (Ana Brochado) and F.O.; formal analysis, A.B. (Adrien Bouchet) and F.O.; investigation, A.B. (Ana Brochado), C.B., A.B. (Ana Brochado) and F.O.; resources, A.B. (Ana Brochado); data curation, A.B. (Ana Brochado) and F.O.; writing-original draft preparation, A.B. (Ana Brochado), C.B., A.B. (Adrien Bouchet) and F.O.; writing-review and editing, A.B. (Ana Brochado), C.B., A.B. (Adrien Bouchet) and F.O. All authors have read and agreed to the published version of the manuscript.

Funding: This research received no external funding.

Institutional Review Board Statement: Not Applicable.

Informed Consent Statement: Not Applicable.

Data Availability Statement: Not Applicable.

Conflicts of Interest: The authors declare no conflict of interest.

\section{References}

1. Appel, H.H. 'Proper museum' or branding platform? Club museums in England. Soccer Soc. 2014, 16, 294-306. [CrossRef]

2. Yang, J. Football Museums: History, Identity, and Connection. Int. J. Hist. Sport 2017, 34, 1872-1882. [CrossRef]

3. Mason, D.S. What is the sports product and who buys it? The marketing of professional sports leagues. Eur. J. Mark. 1999, 33, 402-419. [CrossRef]

4. Pritchard, A.; Cook, D.; Jones, A.; Bason, T.; Salisbury, P.; Hickman, E. Professional sports teams: Going beyond the core. Int. J. Sports Mark. Spons. 2019, 20, 554-566. [CrossRef]

5. Ginesta, X. The business of stadia: Maximizing the use of Spanish Football venues. Tour. Hosp. Res. 2017, 17, 411-423. [CrossRef]

6. Herstein, R.; Jaffe, E.D. Sport hospitality as a business strategy. J. Bus. Strat. 2008, 29, 36-43. [CrossRef]

7. Ramshaw, G.; Gammon, S. On home ground? Twickenham Stadium Tours and the construction of sport heritage. J. Heritage Tour. 2010, 5, 87-102. [CrossRef]

8. Gammon, S.; Fear, V. Stadia tours and the power of backstage. J. Sport Tour. 2005, 10, 243-252. [CrossRef]

9. Bale, J. Sport, Space and the City; Routledge: London, UK, 1993.

10. Hemmington, N. From Service to Experience: Understanding and Defining the Hospitality Business. Serv. Ind. J. 2007, 27, 747-755. [CrossRef]

11. Su, Y.; Teng, W. Contemplating museums' service failure: Extracting the service quality dimensions of museums from negative on-line reviews. Tour. Manag. 2018, 69, 214-222. [CrossRef]

12. Brochado, A.; Stoleriu, O.; Lupu, C. Surf camp experiences. J. Sport Tour. 2018, 22, 21-41. [CrossRef]

13. Brand Finance. Football 50 2019: The Annual Report on the Most Valuable and Strongest Football Brands. Available online: https://brandfinance.com/images/upload/football_50_free.pdf (accessed on 1 October 2020).

14. Crawford, G. Consuming Sport: Fans, Sport and Culture. Int. J. Sports Mark. Spons. 2004, 6, 47-62.

15. Ramshaw, G.; Gammon, S.; Huang, W.-J. Acquired pasts and the commodification of borrowed heritage: The case of the Bank of America Stadium tour. J. Sport Tour. 2013, 18, 17-31. [CrossRef]

16. Frost, W. The sustainability of sports heritage attractions: Lessons from the Australian football league hall of fame. J. Sport Tour. 2005, 10, 295-305. [CrossRef]

17. Ramshaw, G.; Gammon, S.; Tobar, F. Negotiating the cultural and economic outcomes of sport heritage attractions: The case of the National Baseball Hall of Fame. J. Sport Tour. 2019, 23, 79-95. [CrossRef]

18. Rassool, C.; Slade, V. 'Fields of Play': The District Six Museum and the history of football in Cape Town 1. Soccer Soc. 2012, 13, 188-206. [CrossRef] 
19. Magalhães, M.; Horta, P.; Valente, L.; Costa, J. Sports museums as part of the touristic and cultural itineraries: The case of FC Porto and the Dragão stadium. Worldw. Hospit. Tour. Themes 2017, 9, 669-674. [CrossRef]

20. Caber, M.; Albayrak, T. Assessing daily tour service quality: A proposal for a DAILYSERV scale. J. Destin. Mark. Manag. 2018, 7, 18-25. [CrossRef]

21. Cheng, I.M.; Wan, I.K.P. Service quality of Macao museums. J. Qual. Assur. Hospit. Tour. 2012, 13, 37-60. [CrossRef]

22. Cheng, T.-S.; Kuo, N.T.; Chang, K.-C.; Hu, S.M. Integrating the Kano model and IPA to measure quality of museum inter-pretation service: A comparison of visitors from Taiwan and Mainland China. Asia Pac. J. Tour. Res. 2019, 24, 483-500. [CrossRef]

23. Parasuraman, A.; Zeithaml, V.A.; Berry, L.L. Servqual: A multiple-item scale for measuring consumer perceptions of service quality. J. Retail. 1988, 64, 12-40.

24. Frochot, I.; Hughes, H. Histoqual: The development of a historic houses assessment scale. Tour. Manag. 2000, 21, 157-167. [CrossRef]

25. Conti, E.; Vesci, M.; Castellani, P.; Rossato, C. The role of the museumscape on positive word of mouth: Examining Italian museums. TQM J. 2020. [CrossRef]

26. Cunnell, D.; Prentice, R. Tourists' recollections of quality in museums: A service space without people? Mus. Manag. Curatorship 2000, 18, 369-390. [CrossRef]

27. Otto, J.E.; Ritchie, J. The service experience in tourism. Tour. Manag. 1996, 17, 165-174. [CrossRef]

28. McIntosh, A.J. Into the Tourist's Mind: Understanding the Value of the Heritage Experience. J. Travel Tour. Mark. 1999, 8, 41-64. [CrossRef]

29. Doering, Z.D. Strangers, Guests, or Clients? Visitor Experiences in Museums. Curator Mus. J. 1999, 42, 74-87. [CrossRef]

30. Malhotra, N.K. Marketing Research: An Applied Orientation; Pearson Education International: Cranbury, NJ, USA, 2004.

31. Brochado, A.; Troilo, M.; Shah, A. Airbnb customer experience: Evidence of convergence across three countries. Ann. Tour. Res. 2017, 63, 210-212. [CrossRef]

32. Wu, M.-Y.; Wall, G.; Pearce, P. Shopping experiences: International tourists in Beijing's Silk Market. Tour. Manag. 2014, 41, 96-106. [CrossRef]

33. Tkaczynski, A.; Rundle-Thiele, S.R.; Cretchley, J. A vacationer-driven approach to understand destination image: A Leximancer study. J. Vacat. Mark. 2015, 21, 151-162. [CrossRef]

34. Bale, J. The changing face of football: Stadiums and communities. Soccer Soc. 2000, 1, 91-101. [CrossRef] 